\title{
The Status Quo of China's Construction of Free Trade Ports and Related Suggestions
}

\section{Huiling Bao}

Faculty of International Trade, Shanxi University of Finance and Economics, Wucheng Road, Shanxi, China

Keywords: Free trade port; free trade pilot zone; related suggestions; functional positioning

\begin{abstract}
The report of the Nineteenth National Congress of China explicitly stated that "the free trade pilot zone should be given greater reform autonomy and explore the construction of a free trade port." This is the new direction, new goal, and new path pointed out by the General Party Central Committee with General Secretary Xi Jinping at the core in the new era to achieve highquality and high-level development of the Chinese economy. The construction of a free trade port is of significant significance. It is an essential step towards a higher level and higher standards for the construction of existing free trade pilot zones under the guidance of the new journey of reform and opening up. This article summarizes and sorts out the problems existing in the free trade zone in the process of China's reform and opening up, and plans a more productive path according to the problems and implements them.
\end{abstract}

\section{Introduction}

As the second-largest economy in the world, China is continuously absorbing and learning from the development experience of foreign advanced free trade ports and free trade zones in the process of opening up and integrating deeply into the world economic system in all aspects, vast fields, and multiple levels. Domestically, a series of open platforms such as free trade zones, export processing zones, comprehensive bonded zones, and free trade pilot zones have successively landed [1]. The functions of these platforms have undergone three development stages: the first stage is a single "bonded, warehousing and transit" function; the second stage is to add value-added processing functions to meet development needs. In the third stage, the Pilot Free Trade Zone has become a testing ground for "accelerating the transformation of government functions, exploring innovative management models, and promoting trade and investment facilitation.” At present, China's 11 free trade pilot zones have made remarkable progress in many aspects, forming a multi-domain and composite comprehensive reform trend. However, the development of the existing free trade zone pilots is still mainly trying along the road of particular customs supervision areas and is primarily related to the "highly open, highly free and highly convenient" flow of goods, services, capital, people, and high standards for the construction of international free trade ports are far away [2].

\section{Low Degree of Opening-up}

In terms of opening to the outside world, there are still many obstacles and problems in market access related areas in the free trade zone. From the perspective of domestic open markets (trade in goods), the free trade pilot zone cannot solve the problem that the level of market access in China is still low. At present, the China-Korea Free Trade Agreement signed by China is a relatively high level of liberalization agreement. The final tariff rate of zero-tariff products is about $90 \%$. According to the 2016 World Trade Forum (WEF) Global Trade Promotion Report, China 's average applied tariff level is $11.1 \%$, ranking 117th out of 136 countries. Among the 136 countries, the domestic market access ranks 101st, and the foreign market access ranks 124th. This shows that domestic and foreign market access is far behind the overall level of the Asia-Pacific region. In contrast, China remains less open to merchandise trade. Although the free trade pilot zone has the duty-free function, the goods can only enter and leave freely in the exclusive customs supervision zone and are exempt from customs duties. Therefore, the Pilot Free Trade Zone cannot solve the 
essence of China's low level of openness to trade in goods [3-4]. From the perspective of industrial opening, the pre-admission national treatment plus negative list management system was first implemented in the Shanghai Free Trade Pilot Zone in 2013 and is currently implemented in all pilot zones. The negative list has also gradually decreased, and the level of industrial openness in the Pilot Free Trade Zone has significantly improved. The report of the 19th National Congress of the Communist Party of China called for the full implementation of the national treatment plus a negative list management system before admission. This is a fundamental reform of China's foreign investment management system and an important measure to expand opening-up and actively use foreign capital. However, even though the number of negative list items is decreasing, there are still many restrictive measures. Besides, China has not yet fully integrated with the international community in terms of investment form, content, transparency, and definitions, especially in the domestic service industry (such as Finance, shipping, social services, commerce, etc.) are still far behind the international level [5].

\section{Insufficient Economic Freedom}

As far as freedom is concerned, in terms of resolving the relationship between the "government and the market," the free trade pilot zone has formed an institutional innovation system that conforms to the rules of international trade, investment, and business. In terms of utilizing foreign capital, establish a negative list of foreign investment and a national treatment management system before admission; in terms of foreign investment, a filing system for overseas investment management should be established; in terms of foreign trade management, a trade supervision system with trade facilitation as the core should be established. It can be said that the pilot area has made significant progress in promoting the "combination of pipe and tube." However, from the international advanced free port, it is "highly free", that is, "to give full play to the decisive role of the market and leave to the market things that the government should not manage, do not manage, or cannot control." Furthermore, services, as well as market supervision, give full play to these three critical functions and ultimately achieve the goal of the full flow of goods, services, funds, and personnel.” In the future, the pilot areas will mainly face management system innovation and governance [6-7].

\section{The Business Environment Is Not Optimized Enough}

First, related laws on investment and operation of the Pilot Free Trade Zone are still blank, lacking a specific legislative foundation and guarantee, and it is difficult to form a stable and predictable business environment. For example, in terms of intellectual property protection, the Customs Intellectual Property Protection Center is located in the Hengqin Free Trade Zone. It was established in 2017 and gradually strives to meet high standards of international rules in procedures, service content and standards, and dispute resolution. However, in comparison, there is still a large gap, especially in the scope of law enforcement and protection, and in the protection of intellectual property rights of transit goods or bonded goods. The content of the negative list of the free trade zone indicates that it only involves restrictive measures and relevant departments, and does not explain the established principles and legal basis. Therefore, it is not transparent enough. Failure to formulate "future violation measures" following high international standards and failure to refer to "future non-compliance measures" set following high international standards will allow dynamic adjustment of future investment management. Second, we need to accelerate the reform of the tax system in line with international practice. There is still a gap between the international free practice of China's Pilot Free Trade Zone and related tax systems such as foreign trade and offshore finance. First, there is a large gap between the offshore trade taxation system and international practices. The income tax rate of offshore trading enterprises in the zone is high, and it is difficult to attract overseas trading enterprises to conduct business in the free trade pilot zone. The circulation tax burden borne by enterprises in the zone is also relatively high. The tax policies in the zone are not reasonably unified, and the movement of goods in the zone may generate additional tax burdens. 
The second is to accelerate the reform of the tax system in line with international standards. There is still a gap between China's pilot free trade zone and the international development practice of related tax systems such as foreign trade and finance. There is a large gap between the offshore trade taxation system and international practices. The income tax rate of offshore trading enterprises in the zone is high, and it is difficult to attract overseas trading enterprises to conduct business in the free trade pilot zone. The circulation tax burden borne by enterprises in the zone is also relatively high, and a reasonable and unified regional tax policy has not yet been formed. The movement of goods in the zone may generate additional tax burdens.

Based on the above-mentioned relevant content, the attraction of China 's free trade pilot zones to foreign capital is far less than that of domestic capital. Under the global market economy, the advantages of free trade pilot zones are significantly more significant than those of non-free trade pilot zones. Saying is very important. However, compared with foreign investment, because China's business environment has not reached advanced international standards, its influence is weak.

In the forty years of reform and opening-up, China's economy has increased in quality and is now in the tackling phase of transforming development models, optimizing economic structure, and transforming growth momentum. However, China's development is still uneven and inadequate, and all aspects of the construction of a modernized economic system are challenging. Therefore, in the wave of system reforms of "moving the whole body at once", we need to make steady progress and consider all aspects. Based on the many limitations and problems existing in the existing free trade pilot zones, the construction of free trade ports must be brave to lead the trend of reform and opening up in the new period, and actively serve as a guidepost for the course of the times. At least the following characteristics should be reflected in the target positioning. First, it is necessary to accelerate the achievement of quality breakthroughs in the construction of existing free trade zones. In particular, efforts can be made to eliminate the problems mentioned above and deficiencies in opening up, economic freedom, and the business environment, and to realize goods, services, and capital. At the same time as the flow of talents is "highly open, free, and highly convenient", the stress tests opened in China will be gradually expanded and deepened. If not, then in a real sense, a higher level and a high-level free trade port will no longer be possible.

Second, in order to meet the general requirements of "building a modern economic system," as stated in the report of the 19th National Congress of the CPC. It is an inevitable trend to become a comprehensive free trade port integrating export processing, bonded logistics, offshore trade, offshore finance, foreign investment, technological innovation, and business tourism. The trend of shifting from manufacturing and goods trade to services and trade in services has been a critical area for China's opening up to the outside world, and the design of the system of opening up has also extended from the previous "measures on the border" to "measures within the border". Only the construction of a comprehensive and comprehensive free trade port can effectively meet the needs of modern international division of labor and effective global resource allocation, promote a high level of open economy, and strive to achieve reforms and innovations in domestic institutions and mechanisms to form a modern market economic system and a new opening to the outside world. Therefore, the "free economy" category of free trade ports is the pursuit of functional and institutional design, not just the "free trade" category in a pure sense.

Third, we must establish certain advantages in areas that represent the direction of future international competition, namely, trade in services, capital agglomeration, and technological innovation (that is, comprehensive talent gathering). From the perspective of international competition, in order to achieve high-quality development means that China has to transform from a big country to a stable country in either the manufacturing, service or financial technology fields. Under this process, the free trade port is regarded as the forefront of reform and opening up. It must have sufficient foundation, facilities and capabilities to lead the new international competitive advantages of innovative industries. These industries usually include smart manufacturing, modern service industries, Strategic emerging industries, etc., have then become the mainstay of the global supply chain, achieving a truly global center of trade, finance and science and technology innovation. 
Fourth, China must form a free trade port paradigm with Chinese characteristics. The imperfect domestic market economic system, especially the construction of China's free trade port under the background that interest rates and exchange rates have not yet fully realized market operation, will inevitably be branded with "Chinese trademarks" and "Chinese characteristics." The construction of free trade ports should be aligned with the highest international standards. The core is to give full play to the decisive role played by the market in resource allocation and coordinate with the role of the government. Through "tailoring tailoring", customizing and creating an institutional innovationtype system with the characteristics of opening up in the new era and harmonizing with new international economic and trade rules, China's practice of building a free trade port is an integral part of the new road and new model of open-world development.

The report of the 19th National Congress of the Communist Party of China puts forward that "to give greater freedom to reform in the pilot free trade zone and explore the construction of a free trade port," the promotion of experience and the solution of the problem need to be two-pronged.

\section{Methods}

\subsection{Clarify the status of the legal subject and gradually develop the legislative work}

As a particular economic functional area, not just a particular customs supervision area, the goal positioning of the system innovation test field of the free trade port and the free trade pilot zone is quite different. It has the characteristics of "external customs" and "exemption applicable" special laws and regulations. Relatively independent regulatory system mechanisms, management concepts and development orientation will face significant changes. Whether it is to provide a basis for the legitimacy of reform and innovation and sustainable development of free trade ports or to provide protection for the legitimate rights and interests of the subject of activities in the region, it is necessary to follow the internationally accepted practice, that is, "legislation first, then districts" Improving local legislation and essential legislation is a top priority. The second is to clarify the relevant conditions of free trade ports (including the free trade pilot zone), and it can be appropriately relaxed when policies and measures are different from other regions; the third is to clarify related supporting systems, including the enterprise establishment system and the financial supervision system. , The trade and investment promotion system, the customs supervision system, the foreign exchange management system, and the tax collection and management system; the fourth is to fully authorize the legislature where the free trade port is located to make local laws and regulations in line with its functional positioning and development needs. Regulate various business activities in the port area, focus on economic legislation, and remove institutional obstacles to accelerate the implementation of reforms and innovations in free trade ports.

\subsection{Clarify the management system and establish a two-tier management model at the central and local levels}

An active subject is an essential guarantee for the promotion and implementation of a free trade port. A clear subject is conducive to the construction of an orderly management and operation model mechanism and is conducive to overcoming the shortcomings of the innovation management system of the Pilot Free Trade Zone under the current situation. For this reason, the construction of a dual-level management model between the central and local governments is an advantageous choice for China to learn from international success. Based on the authority of the central government, the central government is responsible for the management and coordination of the layout. The Commission makes it the supreme body for the management of free trade zones and free trade ports under the leadership of the State Council. Its responsibilities include, but are not limited to, innovating decision-making mechanisms, formulating development plans, coordinating the promotion and coordination of various issues in the construction and reform of free trade zones and free trade ports, and providing reasonable and useful policy guidance. At the micro-level, local governments need to set up separate management committees with administrative powers to work with local governments. The committees bear Construction-related issues, and the localities can 
perform local general affairs. This management model is conducive to the central government's direct supervision of the development status of free trade ports, clarifies the division of powers between management departments and local governments, and fully releases the space for innovation in the management system of free trade ports.

\subsection{Drawing on international experience and highlighting institutional innovation}

In order to build a free trade port in the light of new era forms, problems, and strategies, China must not only stay at the traditional free trade level, but also learn from the practice of international advanced free ports, and at the same time, it must also highlight institutional innovation with Chinese characteristics. First of all, from the perspective of realizing free trade, the overall layout principle of "first-line deregulation, second-line control, freedom in the area" still needs to be adhered to, and no customs declaration for transshipment goods, no inspection, no statistics, and no taxes on transshipment goods. However, the choice of supervision method can create a free, more efficient and safer image of a free trade port in all aspects, and it can be realized by the model of "physical fence" + "information fence". In the new era of informatization and digitalization, the traditional physical fence mainly focusing on goods trade cannot meet the regulatory requirements of free trade ports in the service industry opening, financial innovation, and investment facilitation. In terms of the free flow of internal and external elements and the optimal allocation of resources, the information fence must be supplemented and used. Second, from the perspective of free capital flow, increase the attractiveness of the RMB in the international market, promote the accelerated internationalization of the RMB, expand the offshore business, allow free distribution of corporate profits and capital in free trade port areas, and implement national treatment before admission. Manage with negative lists. However, in terms of supervision methods, a coordinated financial mixed industry supervision model can be realized and a financial authority can be established. Thirdly, from the perspective of the business environment, streamlining government scale, simplifying administrative functions, and creating a small government model, are currently reasonable choices. Achieving the transfer of some administrative powers of the government is a deepening measure for streamlining administration and decentralization.

\subsection{Clarify the development orientation of china's free trade port and support it with preferential policies}

Its goals determine the positioning of the new era free trade port in the new pattern of opening to the outside world, that is, leading China's new advantages in international competition. Free trade ports need to give corporate and personal income tax concessions or tax deductions in specific areas. The tax policy system should be conducive to participating in international competition, adapting to the environment of cross-border investment and financing, and facilitating the development of offshore financial services. The proposed tax incentives are benchmarked against the global free port offshore business, corporate income tax reduction, indirect tax exemption and other policies that are implemented to gradually narrow the tax gap with international offshore business centers such as Hong Kong, Singapore, and Singapore.

\section{Conclusion}

The construction of a free trade port is expensive but not too much, and its overall goal is high, so it should not be rolled out. At this stage, as a new upland for reform and opening up and institutional innovation, the development of the free trade pilot zone in various places is not limited and unified but can be adapted to local conditions and staggered development. This is also the fundamental intention of the central government to roll out the construction of the free trade pilot zone. However, the goal of free trade port construction does not need to be tested, but should be based on specific target positioning design research and promotion of specific implementation plans, and speed up the implementation, so that the free trade port innovatively benchmarks the international most advanced practices to establish and build a modern economic system 
Benchmarking. In order to make the boundaries between free trade ports and free trade zones very clear, their positioning and goals must be achieved; otherwise the port area is no different. Of course, when choosing a location, it should also be considered in the overall chessboard of the country's overall reform and opening-up layout according to its target positioning. It should not only attach importance to and give preferential treatment to the eastern coastal areas. With the continuous implementation of the coordinated development strategy, it is even more critical to fully exploit the foundation and potential of building free trade ports in inland and border areas. Therefore, it is necessary to carry out the feasibility study on the construction of free trade ports in coastal, inland and border areas, and to speed up the legislative advancement at the top of the country following the regional development characteristics of the economy and the needs of national reform and opening policies Under the design and planning, the new era free trade port will give full play to its due role, that is, carry the mission of the highest reform and opening up.

\section{References}

[1] Yi Zhang, Hong Zhang. The Status Quo, Problems and Legal Construction of China's Collective Construction Land Circulation. Springer Singapore, 2017.

[2] Yi Liu, Jiawen Peng, and Zhihao Yu. 2018. Big Data Platform Architecture under The Background of Financial Technology: In The Insurance Industry as An Example. In Proceedings of the 2018 International Conference on Big Data Engineering and Technology (BDET 2018). ACM, New York, NY, USA, 31-35.

[3] Wang, Li, Zhu, Ji Shuang. Seasonality Analysis of Imported Iron Ore Throughput in China's Coastal Ports. Applied Mechanics \& Materials, 2014, 505-506:950-954.

[4] $\mathrm{Bu}$ Wei, Xiong Yan, Cai Huifeng, etal. Empirical analysis of China's use of FDI and the relationship between FDI and Foreign Trade, Electric Information and Control Engineering (ICEICE), 2011 International Conference on. 2011.

[5] ZHOU Hui, DENG Ke-ke. Status Quo, Problems and Countermeasures of China's Fiscal Budget Transparency. Accounting \& Finance, 2016.

[6] Marta A Geletkanycz, Sylvia Sloan Black. Bound by the past? Experience-based effects on commitment to the strategic status quo. Journal of Management, 27(1):3-21.

[7] Zhang Yanjun, Yang Xiaodong, Liu Yi, Zheng Dayuan, Bi Shujun. Research on the Frame of Intelligent Inspection Platform Based on Spatio-temporal Data. Computer \& Digital Engineering, 2019, 47(03): 616-619+637. 